Originalartikkel

\title{
Fylkesvise forskjeller i overlevelse av brystkreft
}

\begin{abstract}
Sammendrag
Bakgrunn. Et overordnet mål i norsk helsepolitikk er at alle pasienter uavhengig av bosted skal ha samme helsetilbud. Forskjeller i helsetilbud kan føre til ulikheter i sykdomsprognose. Brystkreft er den kreftformen som rammer flest kvinner i Norge. I denne artikkelen sammenlikner vi brystkreftspesifikk overlevelse i landets fylker.
\end{abstract}

Materiale og metode. Vi har utført en populasjonsbasert registerstudie der vi har inkludert alle kvinner i Norge som fikk diagnostisert brystkreft i perioden 1985-2004. Overlevelse av brystkreft analyseres avhengig av bostedsfylke ved ujusterte og justerte hasardrater.

Resultater. 41833 kvinner med brystkreft er inkludert i studien. Ved en gjennomsnittlig oppfølgingstid på 5,8 år døde 16494 (39,4\%), hvorav 9953 (60,3\%) skyldtes brystkreft. Fem års brystkreftspesifikk overlevelse var $74,1-80,6 \%$ i de ulike fylkene. I justerte analyser der man ekskluderte kvinner som ble invitert til screening, var det $20 \%$ forskjell i overlevelse mellom fylkene (HR 0,80; $95 \%$ KI 0,72-0,90; $\mathrm{p}<0,0011$. For pasienter med tumor i stadium 2 var forskjellen på $45 \%$. Behandlingen varierte mellom fylkene, men alle fylkene fulgte samme endringer $\mathrm{i}$ behandling i hele tidsperioden.

Fortolkning. Det er betydelige fylkesvise forskjeller i overlevelse blant kvinner med brystkreft i Norge. Mulige forklaringer kan være ulikt tilbud i mammografiscreening, diagnostikk og behandling.

> Se også side 2583

\section{Mette Kalager}

mette.kalager@kreftregisteret.no

Kreftregisteret

Postboks 5313 Majorstuen

0303 Oslo

\section{Rolf Kåresen}

Erik Wist

Oslo universitetssykehus, Ullevål
Brystkreft er den hyppigste krefttypen hos kvinner i Norge. I 2006 fikk 2673 kvinner og 14 menn brystkreft (1). Aldersstandardisert insidens av sykdommen er nesten blitt fordoblet siden 1960-årene (2), mens dødeligheten har vært relativt stabil (3). Dette betyr at flere kvinner lever med brystkreft $i$ dag, noe som er blitt tilskrevet tidligere diagnose etter innføring av mammografiscreening, mulig overdiagnostisering (4), mer presis diagnostisering og forbedret behandling av sykdommen $(5-8)$.

I Norge har det siden 1981 eksistert nasjonale retningslinjer for behandling av brystkreft utarbeidet av Norsk Bryst Cancer Gruppe (NBCG) (9). Et mål med retningslinjene er å sikre pasientene et enhetlig og godt behandlingstilbud. I 1995-96 ble det norske mammografiprogrammet introdusert i fire prøvefylker: Rogaland, Oslo, Hordaland, Akershus. Fra 1999 ble tilbudet gradvis utvidet til alle landets fylker, og f.o.m. 2004 har programmet vært landsdekkende. Alle kvinner bosatt i Norge i aldersgruppen 50-69 år blir nå invitert til mammografi hvert annet år.

Et overordnet mål i norsk helsevesen er at alle pasienter uavhengig av sosial klasse, bosted og kjønn skal ha samme helsetilbud (10). Det er imidlertid vist for andre sykdommer at det er til dels betydelige forskjeller i prognose og behandlingstilbud avhengig av pasientens bosted og behandlingssykehus (11). Det finnes lite kunnskap om brystkreftprognose relatert til bosted i Norge (12-14). I Sverige er det funnet forskjeller i overlevelse av brystkreft avhengig av pasientens bosted (15).

I denne artikkelen beskrives regionale forskjeller i brystkreftspesifikk overlevelse i Norge i tidsrommet 1985-2004, og vi analyserer faktorer som kan forklare forskjellene.

\section{Materiale og metode}

Studien omfatter alle kvinner i Norge diagnostisert med førstegangstilfelle av infiltrerende brystkreft i perioden 1.11. 1985-31.12. 2004. Til dette formålet har vi brukt informasjon fra Kreftregisteret. I tillegg til cancerdata fra Kreftregisteret har vi brukt den informasjonen om migrasjon og dødsårsak som Kreftregisteret får fra Statistisk sentralbyrå (SSB) og Dødsårsaksregisteret. Det ble hentet ut data om kvinnene til slutten av studieperioden (31.12. 2004) eller til emigrasjon eller død.

Følgende informasjon om kvinnene i Kreftregisteret er brukt: bosted ved diagno- se, dato for første invitasjon til Mammografiprogrammet, tumorstørrelse og -spredning (pTNM-klassifikasjon) (16), tumorstadium og behandling. Tumorstadium er i Kreftregisteret registrert som 1-4, der stadium 1 er lokalisert brystkreft, 2 er brystkreft som har spredd seg til lokale lymfeknuter, 3 er brystkreft som har vokst inn i hud eller thorax, og stadium 4 er brystkreft som har fjernmetastaser. pTNM-klassifikasjonen er kodet i henhold til retningslinjer fra International Agency of Cancer (16).

Informasjon om behandling er basert på kirurgisk meldeskjema for kreftpasienter, patologiremisser og stråleterapidatabasen ved Kreftregisteret. Kirurgisk meldeskjema for brystkreft fylles som regel ut av behandlende kirurg. Dette er et skjema som meldes én gang per brystkrefttilfelle, ofte etter at pasienten er ferdig med den kirurgiske behandlingen av brystkreften, men før hun har startet med annen behandling (strålebehandling, adjuvant behandling og kjemoterapi). Stråleterapidata er overført Kreftregisteret fra landets stråleenheter. Brystkirurgiske inngrep foretatt $\mathrm{i}$ armhulen er registrert fra og med 1993, alle øvrige variabler fra starten av studieperioden. Antiøstrogenbehandling, cytostatikabehandling og stråleterapi er i Kreftregisteret kodet som dikotome verdier (gitt eller ikke-gitt).

Ved etablering av Mammografiprogrammet ble det opprettet 16 brystdiagnostiske sentre, ett i hvert fylke, med unntak av Troms og Finnmark. Agder-fylkene og Trøndelags-fylkene deler ett brystdiagnostiske senter hver. Diagnostikk og behandling av brystkreft i Norge foregår ved disse brystdiagnostiske sentrene samt ved fire sykehus der det ikke er brystdiagnostiske sentre. Våre analyser følger derfor inndelingen av landet etter brystdiagnostiske sentre, da
Hovedbudskap

- Det er et klart mål at alle i Norge skal ha likt helsetilbud

- Behandling av brystkreftpasienter varierer mellom fylkene

- Det er $20 \%$ forskjell i overlevelse av brystkreft mellom fylkene

- Forskjellene kan forklares med ulikt tilbud i mammografiscreening, diagnostikk og behandling 
dette er mest hensiktsmessig for studiens målsetting.

\section{Statistikk}

Analyser av brystkreftspesifikk overlevelse er kalkulert ved bruk av livstabeller og sammenliknet ved logranktest. Sensurering er ved dato for emigrasjon, død av annen årsak enn brystkreft eller på slutten av oppfølgingstiden. I sammenlikningen mellom fylkene har vi regnet hasardrater ved bruk av Cox' proporsjonale hasardmodeller. Rogaland brukes som referansefylke, da dette fylket først startet med organisert mammografiscreening. Vi bruker sannsynlighetsratioanalyser (likelihood) for å sammenlikne de ulike fylkene. Både ujusterte og justerte modeller er kalkulert. I de justerte modellene har vi justert for alder (som en kontinuerlig variabel). Det er ikke justert for tumorstadium, men i stedet er det utført analyser stratifisert etter tumorstadium. Videre er det stratifisert etter om kvinnene er invitert til mammografiscreening eller ikke. Dette er gjort for å ekskludere mulige konfunderende faktorer forbundet ved mammografiscreening. Vi har i tillegg gjort analyser der vi justerer for kalendertid i hvert enkelt fylke for å fange opp uspesifikke endringer som skjer med tiden. Dette har vi gjort ved å lage et interaksjonsledd mellom tid og hvert enkelt fylke. Videre i modellene justerte vi for behandling for å evaluere om det er en assosiasjon mellom fylkesspesifikk overlevelse og behandlingsvariablene. Forutsetningen for proporsjonalitet er testet med grafiske metoder og Schönfelds residualer.

De ulike behandlingsvariablene er beskrevet som prosentandeler i toårsintervaller gjennom studieperioden 1985-2004. Vi presenterer landsgjennomsnittet samt fylkene med henholdsvis høyest og lavest gjennomsnittlig andel av gjenomgått behandling for tidsperioden. Videre vises det fylkesvis forekomst av faktorer som kan ha betydning for prognose, slik som stadiefordeling, andel inviterte til Mammografiprogrammet og utført behandling i perioden.

Resultatene er gitt med $95 \%$ konfidensintervall (KI), dersom det ikke er spesifisert annerledes. P-verdier $<0,05$ anses som statistisk signifikant. Kun tosidige tester er brukt. Vi har ved utregning av konfidensintervall og p-verdier ikke sammenliknet det beste og det dårligste fylket, men brukt de respektive verdiene vi fant ved å bruke Rogaland som referansefylke. Alle analyser er gjort ved hjelp av statistikkprogrammet Stata, versjon 9.2 (StataCorp, College Station, TX, USA).

Studien er godkjent av Norsk samfunnsvitenskapelig datatjeneste (NSD) og strategisk råd ved Kreftregisteret.

\section{Resultater}

I studieperioden ble 41833 kvinner identifisert med primær infiltrerende brystkreft. Tabell 1 gir en oversikt over de ulike basisvariablene i fylkene i studieperioden. Gjen-

Tabell 1 Basisvariabler og utførte behandlinger for kvinner diagnostisert med brystkreft november 1986 - desember 2004 i hvert enkelt fylke etter kvinnens bostedsfylke. Fylkene er rangert etter rekkefølgen de ble innlemmet i mammografiprogrammet ${ }^{1}$. Antall kvinner, prosent i parentes

\begin{tabular}{|c|c|c|c|c|c|c|c|c|c|c|c|}
\hline & \multirow[b]{2}{*}{ Antall } & \multicolumn{5}{|c|}{ Stadium } & \multirow[b]{2}{*}{$\begin{array}{l}\text { Fikk brystbe- } \\
\text { varende kirurgi }\end{array}$} & \multirow{2}{*}{$\begin{array}{c}\text { Fikk vakt- } \\
\text { postlymfe- } \\
\text { knutekirurgi }\end{array}$} & \multirow[b]{2}{*}{$\begin{array}{c}\text { Fikk } \\
\text { tamoksifen }\end{array}$} & \multirow[b]{2}{*}{$\begin{array}{c}\text { Fikk kjemo- } \\
\text { terapi }\end{array}$} & \multirow[b]{2}{*}{$\begin{array}{l}\text { Fikk stråle- } \\
\text { behandling }\end{array}$} \\
\hline & & $\begin{array}{l}\text { Inviterte til } \\
\text { screening }\end{array}$ & 1 & 2 & 3 & 4 & & & & & \\
\hline Hele landet & 41833 & 6960 & $\begin{array}{c}21214 \\
(50,7)\end{array}$ & $\begin{array}{l}15940 \\
(38,1)\end{array}$ & $\begin{array}{l}1900 \\
(4,5)\end{array}$ & $\begin{array}{l}2409 \\
(5,8)\end{array}$ & $7720(18,5)$ & $5606(19,6)$ & $13370(32,0)$ & $9982(23,9)$ & $14847(35,5)$ \\
\hline Rogaland & 3139 & 864 & $\begin{array}{l}1607 \\
(51,2)\end{array}$ & $\begin{array}{l}1171 \\
(37,3)\end{array}$ & $\begin{array}{l}152 \\
(4,8)\end{array}$ & $\begin{array}{l}185 \\
(5,9)\end{array}$ & $664(21,2)$ & $402(17,8)$ & $1041(33,2)$ & $873(27,8)$ & $1296(41,3)$ \\
\hline Oslo & 5866 & 1460 & $\begin{array}{l}3244 \\
(55,3)\end{array}$ & $\begin{array}{l}2034 \\
(34,7)\end{array}$ & $\begin{array}{l}212 \\
(3,6)\end{array}$ & $\begin{array}{l}327 \\
(5,6)\end{array}$ & $1165(19,9)$ & $719(18,6)$ & $1345(22,9)$ & $1266(21,6)$ & $1580(26,9)$ \\
\hline Hordaland & 4008 & 986 & $\begin{array}{l}2099 \\
(52,4)\end{array}$ & $\begin{array}{l}1455 \\
(36,3)\end{array}$ & $\begin{array}{l}190 \\
(4,7)\end{array}$ & $\begin{array}{l}233 \\
(5,8)\end{array}$ & $733(18,3)$ & $422(15,6)$ & $1121(28,0)$ & $1174(29,3)$ & $1654(41,3)$ \\
\hline Akershus & 4283 & 1215 & $\begin{array}{l}2199 \\
(51,3)\end{array}$ & $\begin{array}{l}1645 \\
(38,4)\end{array}$ & $\begin{array}{l}185 \\
(4,3)\end{array}$ & $\begin{array}{l}231 \\
(5,0)\end{array}$ & $799(18,7)$ & $681(22,3)$ & $1135(26,5)$ & $971(22,7)$ & $1718(40,1)$ \\
\hline Telemark & 1702 & 274 & $\begin{array}{c}853 \\
(50,1)\end{array}$ & $\begin{array}{c}646 \\
(38,0)\end{array}$ & $\begin{array}{c}77 \\
(4,5)\end{array}$ & $\begin{array}{r}114 \\
(6,7)\end{array}$ & $453(26,6)$ & $387(33,0)$ & $622(36,6)$ & $399(23,4)$ & $658(38,7)$ \\
\hline Agder & 2354 & 342 & $\begin{array}{l}1147 \\
(48,7)\end{array}$ & $\begin{array}{c}928 \\
(39,4)\end{array}$ & $\begin{array}{l}124 \\
(5,3)\end{array}$ & $\begin{array}{l}139 \\
(5,9)\end{array}$ & $392(16,7)$ & $347(22,0)$ & $941(40,0)$ & $491(20,9)$ & $734(31,2)$ \\
\hline Troms/Finnmark & 1644 & 235 & $\begin{array}{c}830 \\
(50,5)\end{array}$ & $\begin{array}{c}635 \\
(38,6)\end{array}$ & $\begin{array}{c}66 \\
(4,0)\end{array}$ & $\begin{array}{c}96 \\
(5,8)\end{array}$ & $290(17,6)$ & $174(14,9)$ & $482(29,3)$ & $350(21,3)$ & $628(38,2)$ \\
\hline$\emptyset$ stfold & 2362 & 243 & $\begin{array}{l}1239 \\
(52,5)\end{array}$ & $\begin{array}{c}833 \\
(35,3)\end{array}$ & $\begin{array}{l}126 \\
(5,3)\end{array}$ & $\begin{array}{r}145 \\
(6,1)\end{array}$ & $343(14,5)$ & $217(13,5)$ & $754(31,9)$ & $487(20,6)$ & $764(32,4)$ \\
\hline Nordland & 2042 & 212 & $\begin{array}{l}1046 \\
(51,2)\end{array}$ & $\begin{array}{c}798 \\
(39,1)\end{array}$ & $\begin{array}{c}74 \\
(3,6)\end{array}$ & $\begin{array}{c}108 \\
(5,3)\end{array}$ & $404(19,8)$ & $182(12,9)$ & $733(35,9)$ & $445(21,8)$ & $747(36,6)$ \\
\hline Buskerud & 2365 & 284 & $\begin{array}{l}1162 \\
(49,1)\end{array}$ & $\begin{array}{c}899 \\
(38,0)\end{array}$ & $\begin{array}{c}126 \\
(5,3)\end{array}$ & $\begin{array}{l}155 \\
(6,6)\end{array}$ & $392(16,6)$ & $384(23,4)$ & $810(34,3)$ & $497(21,0)$ & $813(34,4)$ \\
\hline Trøndelag & 3455 & 342 & $\begin{array}{l}1694 \\
(49,0)\end{array}$ & $\begin{array}{l}1413 \\
(40,9)\end{array}$ & $\begin{array}{l}135 \\
(3,9)\end{array}$ & $\begin{array}{l}169 \\
(4,9)\end{array}$ & $718(20,8)$ & $554(23,6)$ & $1214(35,1)$ & $747(21,6)$ & $1421(41,1)$ \\
\hline Oppland & 1654 & 153 & $\begin{array}{c}793 \\
(47,9)\end{array}$ & $\begin{array}{c}648 \\
(39,2)\end{array}$ & $\begin{array}{c}84 \\
(5,1)\end{array}$ & $\begin{array}{l}119 \\
(7,2)\end{array}$ & $328(19,8)$ & $165(14,7)$ & $589(35,6)$ & $375(22,7)$ & $628(38,0)$ \\
\hline Møre og Romsdal & 2198 & 153 & $\begin{array}{l}1060 \\
(48,2)\end{array}$ & $\begin{array}{c}913 \\
(41,5)\end{array}$ & $\begin{array}{c}94 \\
(4,3)\end{array}$ & $\begin{array}{l}112 \\
(5,1)\end{array}$ & $372(16,9)$ & $293(19,9)$ & $761(34,6)$ & $602(27,4)$ & $701(32,0)$ \\
\hline Sogn og Fjordane & 892 & 47 & $\begin{array}{c}450 \\
(50,5)\end{array}$ & $\begin{array}{c}339 \\
(38,0)\end{array}$ & $\begin{array}{c}43 \\
(4,8)\end{array}$ & $\begin{array}{c}52 \\
(5,8)\end{array}$ & $112(12,6)$ & $85(14,6)$ & $282(31,6)$ & $226(25,3)$ & $297(33,3)$ \\
\hline Hedmark & 1766 & 80 & $\begin{array}{l}758 \\
(42,9)\end{array}$ & $\begin{array}{c}751 \\
(42,5)\end{array}$ & $\begin{array}{l}113 \\
(6,4)\end{array}$ & $\begin{array}{l}128 \\
(7,3)\end{array}$ & $263(14,9)$ & $242(20,5)$ & $726(41,1)$ & $470(26,6)$ & $572(32,4)$ \\
\hline Vestfold & 2103 & 70 & $\begin{array}{l}1033 \\
(49,1)\end{array}$ & $\begin{array}{c}832 \\
(39,6)\end{array}$ & $\begin{array}{c}99 \\
(4,7)\end{array}$ & $\begin{array}{l}114 \\
(5,4)\end{array}$ & $292(13,9)$ & $352(24,3)$ & $814(38,7)$ & $609(29,0)$ & $636(30,2)$ \\
\hline
\end{tabular}


nomsnittsalderen ved diagnosetidspunkt er 63,3 år, med en fylkesvariasjon fra 60,4 år i Akershus til 64,8 år i Sogn og Fjordane. Ved utgangen av 2004 var $16494(39,4 \%)$ av pasientene døde, og 9953 av disse $(60,3 \%)$ døde av brystkreft. Gjennomsnittlig oppfølgingstid var 5,8 år, maksimum 19,2 år, og $60,6 \%$ av pasientene var i live etter 15 års oppfølgingstid.

\section{Overlevelsesanalyser}

Fem års og ti års brystspesifikk overlevelse for hele landet er henholdsvis 78,6\% og $67,4 \%$ (fig 1). Fem års brystkreftspesifikk overlevelse varierte signifikant mellom fylkene, fra $74,1 \%$ i Hedmark til $80,6 \%$ i Telemark. Ti års overlevelse varierte mellom $61,9 \%$ (Sogn og Fjordane) og 70,0 \% (Telemark og Akershus). De samme forskjellene finner vi også ved stratifisering etter stadium av brystkreft, med en variasjon i femårsoverlevelse mellom fylkene på 86,5-92,2\% for pasienter med brystkreft i stadium $1 \mathrm{og}$ $69,0-81,4 \%$ for pasienter med stadium $2-$ tumorer.

Ved bruk av aldersjusterte regresjonsanalyser finner vi en forskjell i letalitet mellom de ulike fylkene på $24 \%$ (tab 2). Sogn og Fjordane har høyest letalitet (HR 1,09; $95 \%$ KI $0,94-1,26 ; p=0,242)$, mens Hordaland har lavest (HR 0,85; $95 \%$ KI 0,77-0,94; $\mathrm{p}=0,001)$. Det samme mønsteret ser man ved aldersjusterte analyser stratifisert etter brystkreftstadium. For pasienter med brystkreft i tumorstadium 1 er forskjellen i letalitet mellom fylkene på 30\%, Agder med lavest letalitet (HR 0,75; $95 \%$ KI 0,61-0,94; $\mathrm{p}=0,011)$, og Troms/Finnmark med høyest letalitet (HR 1,05; $95 \%$ KI 0,84-1,32; $\mathrm{p}=0,663)$. For tumorstadium 2 er forskjellen på $45 \%$ (Telemark: HR 0,83; $95 \% \mathrm{KI}$ $0,68-1,00 ; p=0,055$ og Sogn og Fjordane: HR 1,28; $95 \%$ KI 1,03-1,59; $\mathrm{p}=0,024$ ). For stadium 3-4 finner vi liknende forskjeller. De samme forskjellene finner vi i analyser der vi har ekskludert kvinner som er invitert til screening.

Når vi justerer for kalendertid i hvert enkelt fylke, finner vi liknende resultat, men noe større forskjeller mellom fylkene. I modellene der vi også justerer for behandling, blir resultatet det samme, men den observerte forskjellen på $29 \%$ er noe større mellom fylkene (HR 1,10-0,81) enn i den ujusterte modellen. Det samme mønsteret ser vi $i$ analysen der kun kvinner som ikke ble invitert til screening er inkludert. Her er forskjellen i letalitet $20 \%$ mellom fylkene når vi justerer for alder (modell 2, tab 2).

\section{Behandling}

Figurene 2-4 viser at det er variasjoner i behandling (bruk av antiøstrogenet tamoksifen, kjemoterapi og stråleterapi) mellom fylkene, og at variasjonene følger samme mønster i hele tidsperioden. Andelen kvinner som blir behandlet med cytostatika, faller brått i begynnelsen av 1990-årene for deretter å stige svakt igjen (fig 2). Dette gjenspeiler at man i midten av 1990-årene sluttet med perioperativ kjemoterapi som rutinebehandling ved operabel brystkreft og gikk over til mer moderne kjemoterapi. I 2004 fikk om lag $25 \%$ av brystkreftpasientene kjemoterapi, mot $35 \%$ i 1986. Tamoksifen gis i økende grad, fra $15 \%$ av pasientene i 1986 til $40 \%$ av pasientene i 2004 (fig 3). Vi ser økende bruk av brystbevarende kirurgi og vaktpostlymfeknutekirurgi (e-fig 5, e-fig 6) i perioden. I gjennomsnitt har $77,8 \%$ av kvinnene som er operert med brystbevarende kirurgi, fått strålebehandling. Andelene varierer mellom 69,5\% og $87,8 \%$ i fylkene (fig 4 ).

\section{Diskusjon}

Denne store populasjonsstudien avdekker betydelige forskjeller i overlevelse av brystkreft mellom fylkene i Norge. Den observerte forskjellen i aldersjusterte hasardrater for brystkreftspesifikk letalitet på $24 \%$ mellom de forskjellige fylkene ( $25 \%$ ved justering for både tid og alder) tilsvarer en forskjell på 7,4\% i absolutt aldersjustert fem års overlevelse mellom det dårligste og det beste fylket.

\section{Styrker og svakheter}

Vår studie har noen begrensninger. Vi har ingen informasjon om tumoren er oppdaget ved rutinescreening eller om kvinnen har hatt symptomer, men vi har informasjon om kvinnen er blitt invitert til Mammografiprogrammet og gjennom det har fått diagnostisert kreft. Noen av behandlingsdataene er hentet fra kirurgisk meldeskjema for kreftpasienter. Meldeskjemaet fylles delvis ut før behandlingen er igangsatt og hvert brystkrefttilfelle rapporteres kun én gang. Behandling av brystkreft er en dynamisk prosess. Dermed kan det bli et misforhold mellom det som rapporteres og den faktiske behandlingen som hver enkelt pasient får. Det er videre til dels mangelfulle opplysninger på meldeskjemaene. Vi har ikke data på tumorgrad, hormonreseptorstatus og HER2status. Dette, sammen med at vi ikke har detaljerte behandlingsvariabler, gjør at vi ikke kan etterprøve om retningslinjene for behandling er fulgt. Videre har vi ikke informasjon om hvilket sykehus som har behandlet kvinnene, kun informasjon om hvilket fylke kvinnen var bosatt $i$ ved tidspunkt for diagnose. Enkelte feilkategoriseringer av pasienter kan derfor ikke utelukkes.

Studiens styrke er det store antall pasienter som er inkludert, dens populasjonsbaserte design, komplettheten av materialet og den lange oppfølgingstiden. Alle krefttilfeller i Norge er siden 1953 registrert i Kreftregisteret, og Kreftregisteret er nær 100\% komplett i sin registrering av solide tumorer (1).

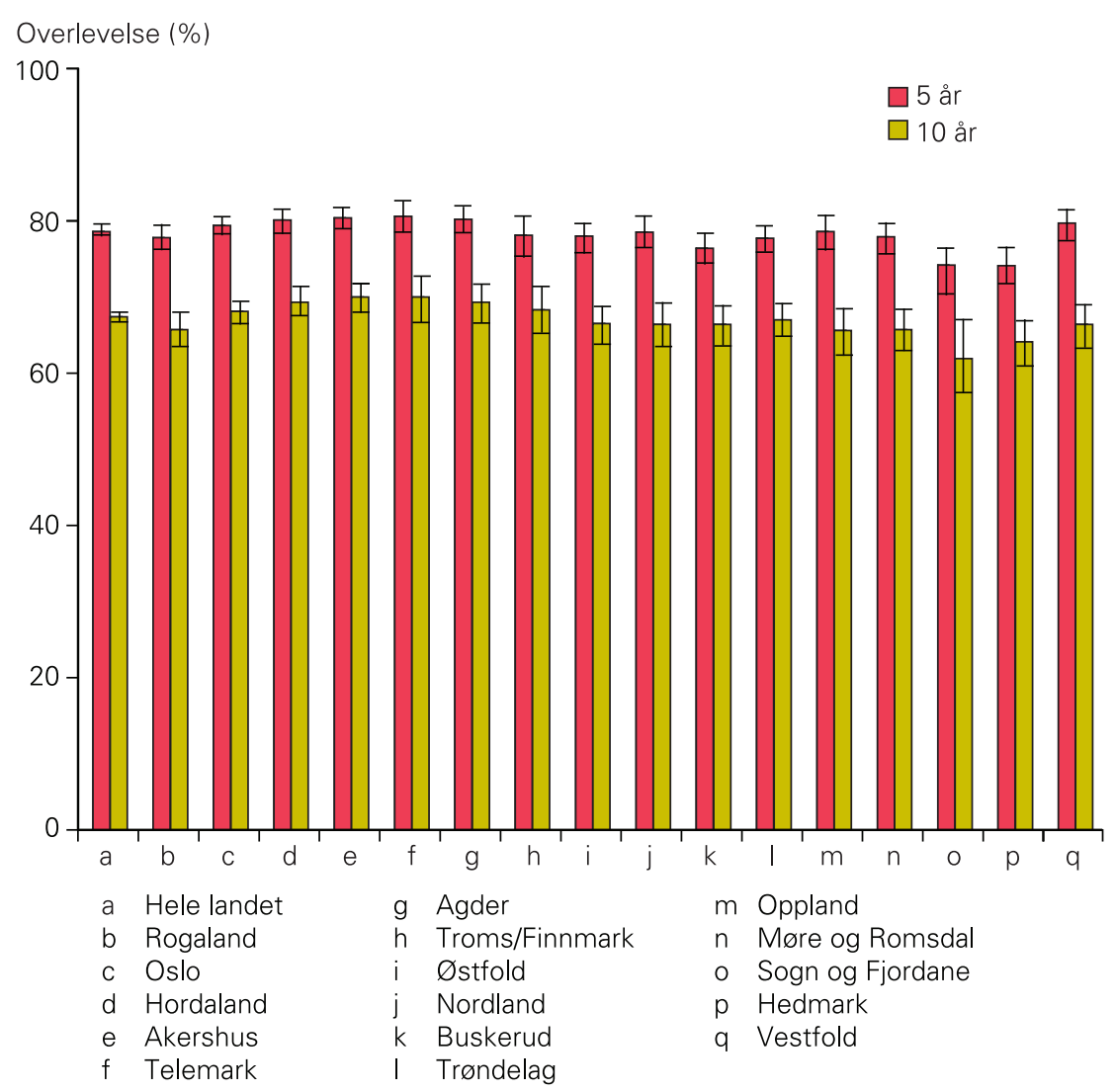

Figur 1 Fem og ti års brystkreftspesifikk overlevelse med $95 \%$ konfidensintervall for kvinner diagnostisert med brystkreft f.o.m. november 1985 t.o.m. desember 2004 i de ulike fylkene 
Tabell 2 Fylkesvise hasardrater (HR) for brystkreftletalitet med $95 \%$ konfidensintervall (KI) og korresponderende p-verdier ved bruk av Cox' regresjonsmodeller. Rogaland er brukt som referansefylke. Fylkene er rangert etter innlemmelse i mammografiprogrammet, det første fylket øverst og det siste nederst

\begin{tabular}{|c|c|c|c|c|c|c|}
\hline & \multicolumn{3}{|c|}{ Modell $1^{1}$} & \multicolumn{3}{|c|}{ Modell $2^{2}$} \\
\hline & $\mathrm{HR}$ & $95 \% \mathrm{KI}$ & P-verdi & $\mathrm{HR}$ & $95 \% \mathrm{Kl}$ & P-verdi \\
\hline Rogaland & 1,00 & ref & & 1,00 & ref & \\
\hline Oslo & 0,89 & $0,82-0,97$ & 0,010 & 0,88 & $0,81-0,97$ & 0,008 \\
\hline Hordaland & 0,85 & $0,77-0,94$ & 0,001 & 0,84 & $0,76-0,92$ & 0,001 \\
\hline Akershus & 0,88 & $0,80-0,97$ & 0,011 & 0,89 & $0,80-0,98$ & 0,019 \\
\hline Telemark & 0,87 & $0,77-0,98$ & 0,024 & 0,82 & $0,72-0,93$ & 0,002 \\
\hline Agder & 0,87 & $0,78-0,97$ & 0,11 & 0,80 & $0,72-0,90$ & $<0,001$ \\
\hline $\begin{array}{l}\text { Troms/ } \\
\text { Finnmark }\end{array}$ & 0,95 & $0,84-1,07$ & 0,374 & 0,88 & $0,78-1,00$ & 0,054 \\
\hline Østfold & 1,00 & $0,89-1,11$ & 0,928 & 0,91 & $0,82-1,01$ & 0,09 \\
\hline Nordland & 0,94 & $0,84-1,06$ & 0,319 & 0,86 & $0,76-0,97$ & 0,011 \\
\hline Buskerud & 1,00 & $0,90-1,11$ & 0,952 & 0,91 & $0,82-1,01$ & 0,10 \\
\hline Trøndelag & 0,94 & $0,86-1,04$ & 0,252 & 0,86 & $0,78-0,95$ & 0,003 \\
\hline Oppland & 0,98 & $0,87-1,10$ & 0,802 & 0,89 & $0,79-1,01$ & 0,073 \\
\hline Møre og Romsdal & 0,96 & $0,86-1,07$ & 0,472 & 0,86 & $0,77-0,97$ & 0,011 \\
\hline Sogn og Fjordane & 1,09 & $0,94-1,26$ & 0,242 & 0,98 & $0,85-1,13$ & 0,768 \\
\hline Hedmark & 1,08 & $0,96-1,21$ & 0,184 & 0,97 & $0,86-1,09$ & 0,573 \\
\hline Vestfold & 0,93 & $0,83-1,04$ & 0,214 & 0,83 & $0,74-0,93$ & 0,001 \\
\hline
\end{tabular}

1 justert for alder ved diagnosetidspunkt

2 justert for alder ved diagnosetidspunkt. I denne analysen har man kun inkludert kvinner som ikke er invitert til mammografiprogrammet
Forskjellene vi finner mellom fylkene kan forklares med forskjellig tilbud om mammografiscreening og forskjell i diagnostikk og behandling. Fylkene implementerte Mam- mografiprogrammet på ulike tidspunkt, og våre resultater kan derfor gjenspeile en effekt av tidlig deteksjon ved screening. Imidlertid finner vi liknende resultater $(20 \%$

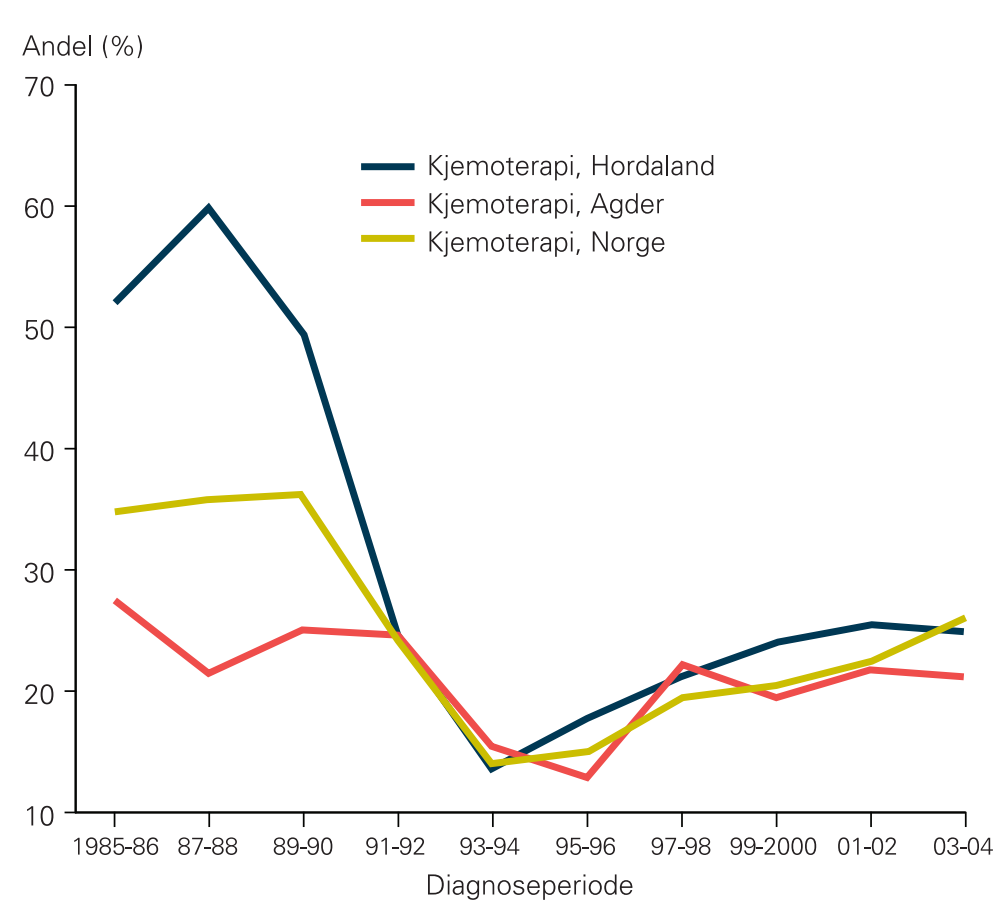

Figur 2 Andel brystkreftpasienter som har fått kjemoterapi i perioden 1.11. 1985-31.12. 2004 i Norge. Her vises de fylkene som har henholdsvis lavest (Agder) og høyest (Hordaland) gjennomsnittlig andel samt totalandelen dødelighetsreduksjon) når vi kun analyserer kvinner som ikke er invitert til programmet (tab 2, modell 2). De observerte forskjellene i overlevelse kan derfor kun i liten grad forklares med mammografiscreeningen $\mathrm{i}$ regi av Mammografiprogrammet. En studie fra Norge viser da også at minst $33 \%$ av dødelighetsreduksjonen etter innføring av Mammografiprogrammet skyldes andre faktorer enn selve screeningen (17). Variasjonene i oppmøte til screening mellom fylkene er små, om lag $26 \%$ som ikke møter, med unntak av Oslo der oppmøtet for perioden var på $60 \%$ (data fra mammografiscreeningsdatabasen). Det er derfor lite trolig at forskjeller i oppmøte har betydning for fylkesforskjellene. Imidlertid ser vi større ulikheter i letalitet mellom fylkene etter 1995. Dette kan delvis reflektere screening utenfor Mammografiprogrammet. Videre ser vi at fordelingen av tumorstadium varierer lite mellom fylkene. Det ser ut til at det er større forskjeller på overlevelse mellom fylkene innenfor hvert enkelt stadium enn forskjeller mellom stadiefordelingen i hvert enkelt fylke. Fordelingen av tumorstadium kan derfor heller ikke fullt ut forklare de observerte letalitetsforskjellene.

Den største forskjellen i overlevelse mellom fylkene finnes i tumorstadium 2. Vi ser at det er forskjeller i bruk av vaktpostlymfeknutekirurgi (e-fig 6) mellom fylkene, som kan gi seg utslag i stadiemigrasjon (18). Av den grunn finner man flere pasienter med lymfeknutemetastaser enn man gjorde før man hadde denne type diagnostikk $(8,19)$. Åpenbart øker denne diagnostikken overlevelsen hos pasienter med svulster i stadium $1 \mathrm{og}$ stadium 2 (18). Det er til dels store forskjeller i bruk av denne mellom fylkene i den aktuelle tidsperioden $(8,9-22,7 \%)$, noe som kan være med på å forklare deler av dødelighetsforskjellene mellom fylkene innenfor hvert enkelt stadium. Imidlertid har dette liten betydning for forskjellen i overlevelse som vi finner for de enkelte fylkene for hele tidsperioden, da vi finner forskjeller i letalitet uavhengig av tumorstadium.

Det er også beskrevet geografiske forskjeller i dødelighet av brystkreft i Sverige og England. Disse tilskrives i hovedsak bedret diagnostisering og behandling i form av tverrfaglig samarbeid $(15,20)$. Andre studier har vist sammenheng mellom kirurgvolum og dødelighet ved avanserte kirurgiske inngrep $(21,22)$. Dette kan også være tilfelle for kirurgisk behandling av brystkreft (23-27). Man diskuterer om den økte overlevelsen kan forklares gjennom bedret kirurgi eller om det er den enkelte brystkreftkirurgen som i større grad henviser til høyspesialiserte brystonkologer (28, 29). Ifølge en nylig publisert studie er totaldødeligheten, men ikke brystkreftdødeligheten, lavere blant kvinner operert av kirurger med et høyere volum (29). Årsaken kan være at det er de kvinnene som er friskest i utgangspunktet som henvises til de mest spesiali- 
serte kirurgene. I en annen studie der man undersøkte kvinner som var død én måned etter at de hadde fått brystkreftkirurgi, fant man at $59 \%$ av kvinnene ble gitt en annen dødsårsak enn brystkreft (30). På den annen side viser en studie fra Norge at kvinner som har flere sykdommer i tillegg til brystkreft, lever kortere enn kvinner som kun har brystkreft (31).

Andre faktorer som kan ha betydning for prognose av brystkreft, er sosioøkonomisk status, utdanningslengde, antall barn, bruk av hormonpreparater, alder ved menopause og menopausalstatus. En norsk studie viste imidlertid at det ikke var forskjeller i brystkreftdødelighet mellom sosiale grupper i Norge. Forfatterne mente at dette kunne maskeres av mammografiscreening (32). Det er fylkesforskjeller i salgsvolum av hormonpreparater, men disse er ikke store. Et unntak er Hedmark, som har høyere salgstall enn de andre fylkene (data fra 2004) (33). Det er kun små forskjeller i fødselsratene mellom de norske fylkene (34). Det er derfor lite trolig at disse faktorene kan forklare de til dels store forskjellene i overlevelse vi ser mellom fylkene.

For Rogaland kan forklaringen på den forholdsvis høye letaliteten være at det er opphopning av BRCA1-bærere (35). Disse bærerne har betydelig dårligere prognose enn dem som ikke har dette genet. Fem års overlevelse for dem er $73 \%$ (36), mens den er $85,3 \%$ i totalpopulasjonen (1996-2000) (1). Vi kan derfor ikke helt forklare forskjellen vi ser i overlevelse i de norske fylkene med de ovenfor nevnte variabler. Våre behandlingsdata indikerer at det er til dels store forskjeller i tilbudet om diagnostikk og behandling. Raabe og medarbeidere fant $i$ en studie fra Oslo i 1980-89 at om lag en tredel av brystkreftpasientene ikke fikk den antiøstrogenbehandlingen som de etter retningslinjene skulle ha hatt (13). Våre data er imidlertid for mangelfulle til å finne en klar sammenheng mellom dødelighet og manglende behandling. For å studere denne sammenhengen må vi ha sikrere data på at anbefalt behandling virkelig er blitt gitt. Trolig må vi også studere den enkelte behandler og hans eller hennes prestasjoner $(21,22-27)$. I hvilken grad mammografiscreening og forbedret behandling innvirker på de fylkesvise forskjellene i overlevelse, kan man ikke si uten å ha fått informasjon om brystkreftsvulsten er oppdaget ved screeningmammografi eller ved mammografi utført på bakgrunn av pasientens symptomer. I tillegg må man ha mer detaljerte og utfyllende opplysninger om behandling av hver enkelt pasient. Norsk Bryst Cancer Gruppe og Kreftregisteret arbeider for tiden med et klinisk brystkreftregister der all behandling av alle brystkreftpasientene $\mathrm{i}$ Norge skal registreres. Når dette registeret er i fullt bruk, håper vi at man kan studere og etterprøve om alle brystkreftpasienter får samme tilbud om behandling uavhengig av bosted og sosial klasse.

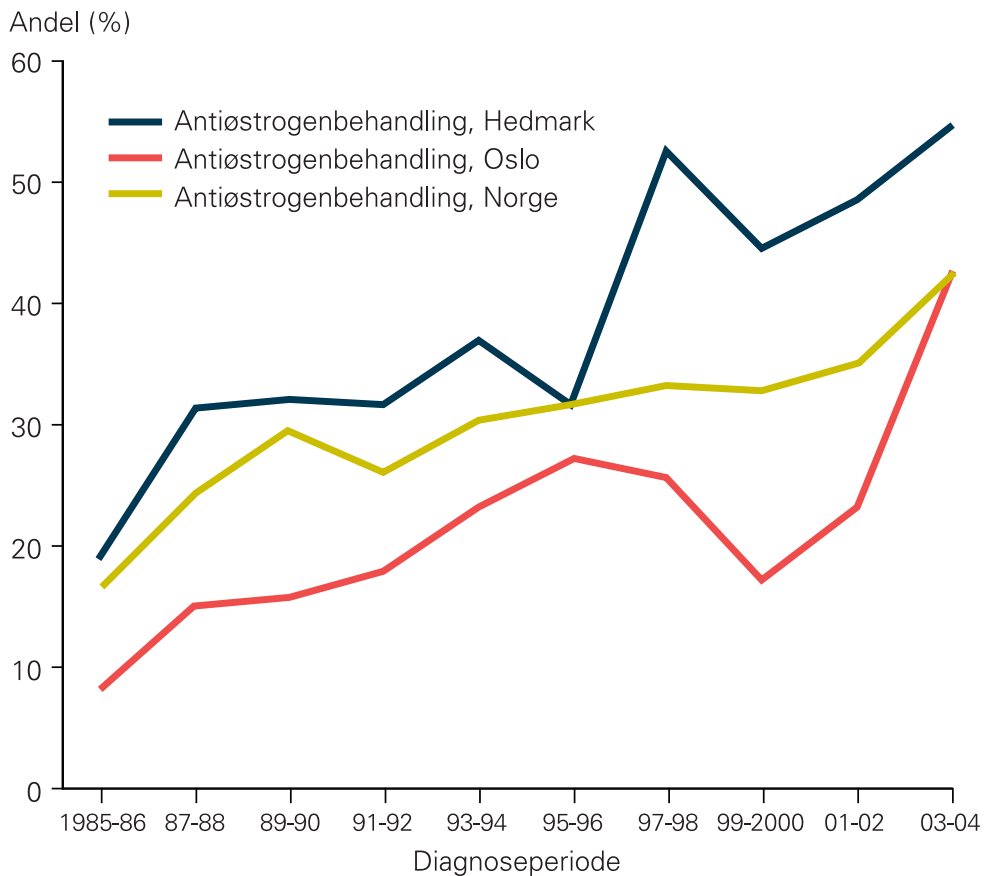

Figur 3 Andel brystkreftpasienter som har fått antiøstrogen behandling i perioden 1.11. 198531.12. 2004 i Norge. Her vises de fylkene som har henholdsvis lavest (Oslo) og høyest (Hedmark) gjennomsnittlig andel samt totalandelen
Våre data viser at overlevelse av brystkreft i Norge har bedret seg gjennom hele tidsperioden. Forskjellen i overlevelse mellom kvinner som diagnostiseres tidlig (slutten av 1980-årene) og sent (2000) i studiepe- rioden, blir noe mindre når vi justerer for behandlingsvariablene og stratifiserer etter screening. Likevel er denne bedringen i overlevelse trolig et uttrykk for at behandling av brystkreft generelt blir bedre, kvin-

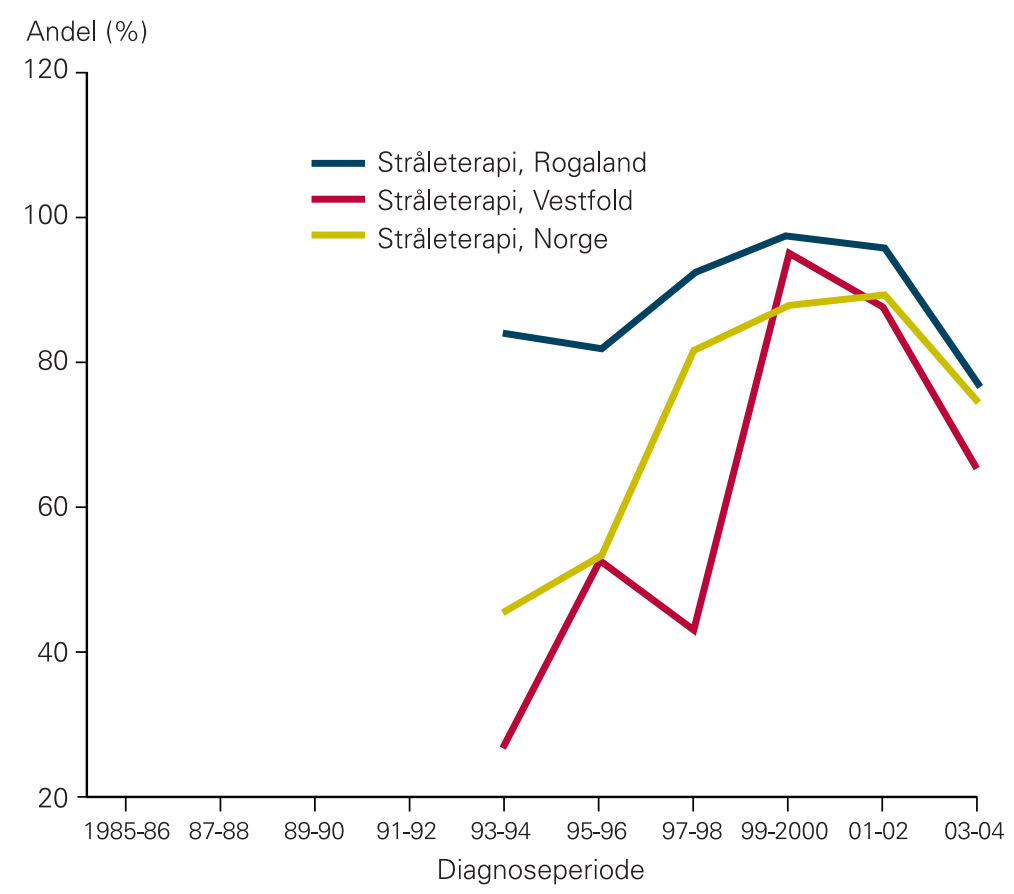

Figur 4 Andel kvinner som har fått stråleterapi etter brystbevarende kirurgi fra 1993-2004. Her vises de fylkene som har henholdsvis lavest (Vestfold) og høyest (Rogaland) gjennomsnittlig andel samt totalandelen 
ner er mer oppmerksomme på sykdommen og oppsøker lege tidligere i sykdomsforløpet, og tilbudet om screening for brystkreft har økt.

Vi takker Hans-Olov Adami for verdifulle kommentarer til studien, Harald Weedon Fekjær for statistisk kompetanse og nyttige diskusjoner og medarbeidere ved Kreftregisteret for datauttrekk og stor databasekompetanse.

\section{Oppgitte interessekonflikter: Ingen}

e-fig 5 og e-fig 6 finnes i artikkelen på www.tidsskriftet.no

\section{Litteratur}

1. Kreftregisteret. Cancer in Norway 2006 www.kreftregisteret no (15.4.2009).

2. Kreftregisteret. Kreftstatistikk www.kreftregisteret.no/no/Registrene/ Kreftstatistikk/ [15.4.2009]

3. Statistisk sentralbyrå Statistikkbanken. Helse sosiale forhold og kriminalitet. http://statbank ssb.no/statistikkbanken/Default_FR.asp? Productid $=03.01 \& P X S i d=0 \& n v l=$ true $\& P$ Language $=0 \&$ tilside $=$ selecttable/MenuSelP asp\&SubjectCode $=03$ (13.9.2008)

4. Zahl PH, Strand BH, Mæhlen J. Incidence of breast cancer in Norway and Sweden during introduction of nationwide screening: prospective cohort study. BMJ 2004; 328: 921 -4

5. Nyström L, Andersson I, Bjurstam $\mathrm{N}$ et al. Long term effects of mammography screening: updated overview of the Swedish randomised trials. Lancet 2002; 359: 909-19.

6. Early Breast Cancer Trialists' Collaborative Group. Effects of chemotherapy and hormonal therapy for early breast cancer on recurrence and 15-year survival: an overview of the randomised trials. Lancet 2005; 365: 1687-717.

7. Stockton D, Davies T, Day N et al. Retrospective study for reasons for improved survival in patients with breast cancer in East Anglia: earlier diagnosis or better treatment? BMJ 1997; 314: 472-5.

8. Giuliano AE, Dale PS, Turner RR et al. Improved axillary staging of breast cancer with sentinel lymphadenectomy. Ann Surg 1995; 222: 394-9.

9. Norsk Bryst Cancer Gruppe. www.nbcg.no/ nbcg.blaaboka.html (27.4.2009).
10. St.prp. nr 1 (2005-2006). Strategisk arbeid på kreftområdet. www.regjeringen.no/nb/dep/hod/ dok/regpubl/stprp/20052006/Stprp-nr-1-20052006-/7.html?id=211309 (27.4.2009).

11. Dalgard OS, Rognerud M. Strand BH. Psykisk helse i Helse- og levekårsundersøkelsen i 1998. II. Geografiske forskjeller. Norsk Epidemiologi 2002; 12: 249-56. www.ub.ntnu.no/journals/norepid/ 2002-3/2002(3)Dalgard.pdf (15.4.2009).

12. Raabe NK, Fossa SD, Karesen R. Primær invasiv cancer mammae i Oslo 1980-89. Tidsskr Nor Lægeforen 1997; 117: 3778-83.

13. Raabe NK, Kaaresen R, Fosså SD. Analysis of adjuvant treatment in postmenopausal patients with stage II invasive breast carsinoma. A pattern of care study and quality assurance of 431 consecutive patients in Oslo. Acta Oncol 1997; 36: 255-60.

14. Kravdal $\varnothing$. Does place matter for cancer survival in Norway? A multilevel analysis of the importance of hospital affiliation and municipality socio-economic resources. Health Place 2006: 12: 527-37.

15. Eaker S, Dickman PW, Hellström V et al. Regional differences in breast cancer survival despite common guidelines. Cancer Epidemiol Biomarkers Prev 2005; 14: 2914-8.

16. Sobin LH, Wittekin $C$, red. TNM classification of malignant tumors. 6. utg. Hoboken, NJ: John Wiley \& Sons, 2002

17. Kalager M, Haldorsen T, Bretthauer M et al. Improved breast cancer survival following introduction of an organized mammography screening program among both screened and unscreened women: a population-based cohort study. Breast Cancer Res 2009; 11: R44

18. Feinstein AR, Sosin DM, Wells CK. The Will Rogers phenomenon. Stage migration and new diagnostic techniques as a source of misleading statistics for survival in cancer. N Engl J Med 1985; 312: $1604-8$.

19. van Rijk MC. Peterse JL, Nieweg OE et al. Additional axillary metastases and stage migration in breast cancer patients with micrometastases or submicrometastases in sentinel lymph nodes. Cancer 2006; 107: 467-71.

20. Mullee MA, De Stavola B, Romanengo M et al. Geographical variation in breast cancer survival rates for women diagnosed in England between 1992 and 1994. Br J Cancer 2004; 90: 2153-6.

21. Birkmeyer JD, Stukel TA, Siewers AE et al. Surgeon volume and operative mortality in the United States. N Engl J Med 2003: 349: 2117-27.

22. Begg CB, Riedel ER, Bach PB et al. Variations in morbidity after radical prostatectomy. $\mathrm{N}$ Engl J Med 2002; 346: 1138-44.
23. Sainsbury R, Haward B, Rider L et al. Influence of clinician workload and patterns of treatment on survival from breast cancer. Lancet 1995; 345: 1265-70.

24. Skinner KA, Helsper JT, Deapen D et al. Breast cancer: do specialists make a difference? Ann Surg Oncol 2003; 10: 606-15.

25. Gilligan MA, Neuner J, Zhang X et al. Relationship between number of breast cancer operations performed and 5-year survival after treatment for early-stage breast cancer. Am J Public Health 2007; 97: 539-44

26. Gillis C, Hole D. Survival outcome of care by specialist surgeons in breast cancer. A study of 3786 patients in the west of Scotland. BMJ 1996:312: $145-8$

27. Kingsmore D, Hole D, Gillis C. Why does specialist treatment of breast cancer improve survival? The role of surgical management. Br J Cancer 2004: 90: $1920-5$

28. Pass Ha, Klimberg SV, Copeland EM $3^{\text {rd }}$. Are breast-focused surgeons more competent? Ann Surg Oncol 2008; 15: 953-5.

29. Nattinger AB, Laud PW, Sparapani RA et al. Exploring the surgeon volume-outcome relationship among women with breast cancer. Arch Intern Med 2007; 167: 1958-63.

30. Welch HG. Black WC. Are deaths within 1 month of cancer-directed surgery attributed to cancer? J Natl Cancer Inst 2002; 94: 1066-70.

31. Tjemsland L, Søreide JA. Når kreftsykdommer kommer i tillegg...Tidsskr Nor Lægeforen 2001; 121: $1046-51$

32. Robsahm TE, Tretli S. Weak associations between sociodemographic factors and breast cancer: possible effects of early detection. Eur J Cancer Prev 2005; 14: 7-12.

33. Folkehelseinstituttet. Reseptregisteret. www.reseptregisteret.no (13.9.2008)

34. Statistisk sentralbyrå. Samlet fruktbarhetstall. www.ssb.no/emner/02/02/10/fodte/tab-2009-0402-05. html (23.4.2009).

35. Møller P, Heimdal K, Apold J et al. Genetic epidemiology of BRCA1 mutations in Norway. Eur J Cancer 2001; 37: 2428-34.

36. Møller P. Evans DG, Reis $M$ et al. Surveillance for familial breast cancer: Differences in outcome to BRCA mutation status. Int J Cancer 2007; 121: 1017-20.

Manuskriptet ble mottatt 6.1. 2009 og godkjent 24.9. 2009. Medisinsk redaktør Erlend Hem. 